\title{
NORMÁLIRÁNYBAN TERHELT KOMPOZIT- ÉS ACÉLLEMEZ ÖSSZEHASONLÍTÁSA
}

\author{
Havellant András \\ hallgató, Miskolci Egyetem, Müszaki Mechanikai Intézet \\ 3515 Miskolc, Miskolc-Egyetemváros, email: havandris@gmail.com \\ Kiss László \\ adjunktus Miskolci Egyetem, Müszaki Mechanikai Intézet \\ 3515 Miskolc, Miskolc-Egyetemváros, email: mechkiss@uni-miskolc.hu
}

\begin{abstract}
Absztrakt
Ez a tanulmány a kompozitok általános tulajdonságairól ad egy rövid áttekintést. A lineáris rugalmasságtan keretein belül sor kerül az anyagegyenletek ismertetésére, külön kiemelve az általánosan ortotrop anyagi viselkedést. Ezek után egy lemez alkatrész végeselemes vizsgálata demonstrálja egy epoxy mátrixú grafit erösitöszálakat tartalmazó kompozit adta tömegcsökkentési lehetöséget egy általános acélhoz képest.
\end{abstract}

Kulcsszavak: kompozit, végeselem, lemez, ortotrop anyag

\begin{abstract}
This study gives a brief overview about the general properties of composite materials. Within linear elasticity, the constitutive equations are given with special emphasis on generally orthotropic material behaviour. Afterwards, the finite element simulation of a plate is carried out to demonstrate how the mass of a plate can be reduced using graphite-epoxy fiber reinforced composite material instead of a general purpose steel.
\end{abstract}

Keywords: composite, finite element, plate, orthotropic material

\section{Bevezetés}

Napjainkban a kompozitok már igen széles körben elterjedt anyagok. A müszaki gyakorlatban számos alkalmazási területük van, csak egy párat említve; a repülőgépipar, az építőipar, de sporteszközök gyártásánál is kitüntetett szerepük van.

A legtöbb gépben, alkatrészben, használati tárgyban a terhelés eloszlása, iránya nem azonos a tér minden irányában, de egy kitüntetett irány pontosan meghatározható. Ezeknek az erővonalaknak az irányában jelentősen jobb mechanikai tulajdonságok (szívósság, merevség) szükségesek, mint más irányokban. Ezt a szükséget elégítik ki a kompozitok, ahol a homogén szerkezeti anyagot a szükséges irányban nagyobb szilárdságú anyaggal erősítik meg.

A kompozitok jellemzően többfázisú anyagok, melyek a befoglaló anyagból (későbbiekben mátrix) és az erősítőanyagból állnak (1. ábra). Az erősítőanyag nagy rugalmassági moduluszú és szilárdságú, míg a mátrix szilárdsága általában kisebb az erősítőanyagénál. A két fázis között adhéziós kapcsolat van, mely nagymértékü igénybevétel esetén is fennmarad. Az erősítőanyag feladata az, hogy biztosítsa a szerkezet szilárdságát és merevségét, míg a mátrix szerepe az, hogy összefogja és védje az 
erősítőanyagot a külső behatásoktól, és biztosítsa a terhelés egyenletes eloszlását a keresztmetszet mentén [1].

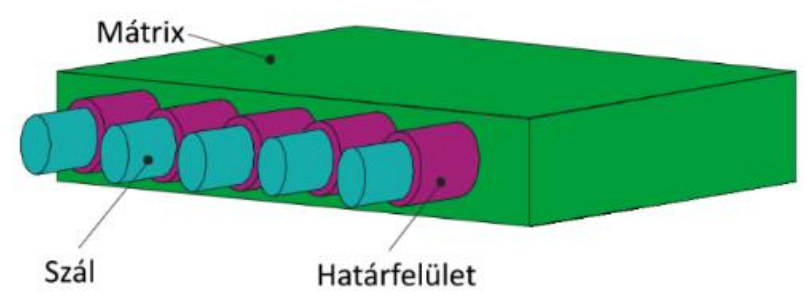

1. ábra. A kompozitok elvi felépitése. [2]

Általánosságban elmondható, hogy a kompozitok az alábbi előnyökkel, illetve hátrányokkal rendelkez(het)nek a klasszikus egynemü anyagokkal szemben:

+ kedvezőbb mechanikai és hőtágulási tulajdonságok,

+ jóval kisebb saját tömeg,

+ előnyös korrózióval és kifáradással szembeni ellenállás,

- magasabb kezdeti költségek (amik idővel megtérülhetnek),

- drágán, illetve nehezen javíthatók és a cseréjük is költségesebb.

A kompozitokra vonatkozó szakirodalom szerteágazó, rengeteg ismerettel rendelkezünk. Igen jelentős mennyiségü és változatos probléma megoldására került már sor numerikusan és analitikusan is. Kiváló összefoglalót nyújt az alapvető ismeretekről például Kollár és Springer könyve [3], amely részletesen leírja a kompozitok mechanikáját. Az elmozdulások, nyúlások, feszültségek témakörének tisztázása mellett rengeteg analitikusan megoldott példa található benne rudakra és héjakra egyaránt.

Ami a kompozit lemezeket illeti, számos forrás elérhető. A [4] értekezés például saját síkjukban terhelt, nem szimmetrikusan laminált lemezek nyomással szembeni viselkedését (kihajlását) vizsgálja geometriailag lineáris és nemlineáris modellekkel egyaránt. Érdemes még megemlíteni az [5] cikket, ami rugalmasan ágyazott kompozit lemezek vizsgálatakor a klasszikusnál pontosabb modellt használva, figyelembe veszi a nyírási deformációkat is. A [6] szerzői végeselemes számításokkal és kísérleti eredményekkel vizsgálják szálas polimer kompozitok mechanikai viselkedését és tönkremenetelét egytengelyü húzófeszültség esetén. A tapasztalatok jó egyezést mutatnak a két különböző technika között. A [7] cikk bemutat egy Kármán-Mindlin lemezelméleten alapuló nemlineáris végeselemes módszert, amivel vékony rétegekből álló lemezek transzverzális alakváltozásait lehet számítani. Fontos eredmény, hogy sor került a leggyengébb réteg tönkremeneteléhez tartozó terhelés meghatározására is. A [8] disszertáció textil kompozitok numerikus analízisét tárgyalja, melyet anyagvizsgálatokkal is kiegészít. A [9] dolgozat az ép és delaminált lemezek lengéstani viselkedését vizsgálja, és kitér olyan jelenségekre is, mint a kompozit lemezek sajátkörfrekvenciájának nemlineáris változása. A [10] forrás szálas kompozitokra fókuszálva tárgyalja az összetevők tulajdonságai mellett az egy- és többcellás szendvics cellalemezek számítási és optimalizálási módszereit, emellett profilos tartók és cellalemezek esetén vizsgálja a kompozitok alkalmazásával elérhető tömegcsökkentés lehetőségét.

$\mathrm{Az}$ irodalomban számos további, nem homogén anyagból készült alkatrész mechanikai viselkedésével foglalkozó forrás érhető el - lásd például a [11], [12], [13], [14], [15] és [16] munkákat.

A fenti rövid áttekintés alapján megállapítható, hogy a szálerősítésủ lemezek klasszikus mechanikai modellezésénél leggyakrabban használt egyszerüsítő feltevések az alábbiak:

- Az alkatrész ideálisan összekapcsolt ortotrop régetekből áll. A keresztirányú elmozdulások folytonosak a vastagság mentén. 
- Az elmozdulások és alakváltozások jellemzően kismértékủek.

- Az anyag lineárisan rugalmas.

- A vastagság jóval kisebb, mint a másik két irányú kiterjedés.

- A mechanikai terhelés hatására bekövetkező hőhatások általában elhanyagolhatók.

A lineáris rugalmasságtan keretein belül a cikk a továbbiakban ismerteti az anyagegyenleteket, külön kiemelve az általánosan ortotrop anyagi viselkedés leírását. Ezután egy egyszerü, de szemléletes példán keresztül kerül bemutatásra a kompozitok használatával elérhető egyik legnagyobb előny a klasszikus anyagokkal szemben, ami a tömegcsökkentés. A numerikus szimulációkhoz az Abaqus kereskedelmi végeselemes szoftver nyújtott segítséget. A cikket összefoglalás és irodalomjegyzék zárja.

\section{Anyagi viselkedés}

\subsection{Az általános anyagi modellezés}

Térbeli feszültségi állapotban, lineárisan rugalmas, általános anizotróp, anyagi viselkedés mellett 9 koordinátája van mind a $\underline{\underline{\sigma}}$ feszültségi-, mind az $\underline{\underline{\varepsilon}}$ alakváltozási tenzornak. A kapcsolat a feszültségek és alakváltozások között a legáltalánosabb alakban a

$$
\begin{aligned}
& {\left[\sigma_{i j}\right]=\left[C_{i j k l}\right]\left[\varepsilon_{k l}\right], \quad i, j, k, l=\{1,2,3\}} \\
& (3 \times 3) \quad(9 \times 9)
\end{aligned}
$$

formában adható meg. Itt $\underline{\underline{C}}$ az anyagállandók negyedrendủ mátrixa három a negyediken koordinátával, vagyis összesen 81 elemet (anyagállandót) tartalmaz. Az első két index a feszültségekre vonatkozik, a második pár pedig az alakváltozásokra. A $\underline{\underline{\sigma}}$ feszültségi- és az $\underline{\underline{\varepsilon}}$ alakváltozási tenzorok esetében fennálló szimmetria miatt nem 9-9, hanem egyenként csak 6 független elemük van. Következőleg, az anyagállandók esetén is fenn kell állnia szimmetriának az első és az utolsó két index vonatkozásában. Azaz például teljesülnie kell, hogy

$$
C_{i j k l}=C_{j i k l}, C_{i j k l}=C_{i j l k}
$$

Ennélfogva belátható, hogy a független anyagállandók száma már csak 36, így pedig célszerủ áttérni a

$$
\begin{aligned}
& {[\underline{\underline{\sigma}}]=[\underline{\underline{C}}][\underline{\underline{\varepsilon}}]} \\
& (6 x 1)(6 x 6)(6 x 1)
\end{aligned}
$$

mátrixos alakra, ahol az egyes feszültségi- és alakváltozási koordinátákat a következőképpen értelmezzük:

$$
\begin{gathered}
\sigma_{1}=\sigma_{11}, \sigma_{2}=\sigma_{22}, \sigma_{3}=\sigma_{33}, \sigma_{4}=\sigma_{23}=\sigma_{32}, \\
\sigma_{5}=\sigma_{13}=\sigma_{31}, \sigma_{6}=\sigma_{12}=\sigma_{21}
\end{gathered}
$$

valamint

$$
\begin{aligned}
& \varepsilon_{1}=\varepsilon_{11}, \varepsilon_{2}=\varepsilon_{22}, \varepsilon_{3}=\varepsilon_{33}, \varepsilon_{4}=\gamma_{23}=\gamma_{32}=2 \varepsilon_{23}=2 \varepsilon_{32}, \\
& \varepsilon_{5}=\gamma_{13}=\gamma_{31}=2 \varepsilon_{13}=2 \varepsilon_{31}, \varepsilon_{6}=\gamma_{12}=\gamma_{21}=2 \varepsilon_{12}=2 \varepsilon_{21}
\end{aligned}
$$


ahol $\varepsilon_{i i}$ a fajlagos nyúlást, $\gamma_{i j}$ a fajlagos szögtorzulást jelöli. Megjegyzendő, hogy a (3) összefüggés helyett gyakran az

$$
[\underline{\underline{\varepsilon}}]=[\underline{\underline{D}}][\underline{\underline{\sigma}}]
$$

inverz alakot használják, ahol $\underline{\underline{D}}=\underline{\underline{C}}^{-1}$.

A független anyagállandók száma még tovább csökken. Ez egyfajta következménye a $W$ fajlagos alakváltozási energia létezésének. A (kezdeti) térfogategységre jutó alakváltozási energia

$$
W=\frac{1}{2} \sigma_{i} \varepsilon_{i}=\frac{1}{2} C_{i j} \varepsilon_{j} \varepsilon_{i}
$$

aminek második deriváltja

$$
\frac{\partial W}{\partial \varepsilon_{i} \partial \varepsilon_{j}}=\frac{\partial W}{\partial \varepsilon_{j} \partial \varepsilon_{i}}=C_{i j}
$$

értelemszerüen független a deriválás sorrendjétől, azaz

$$
C_{i j}=C_{j i} .
$$

Emiatt pedig a ténylegesen független anyagállandók száma 21 .

Fontos megemlíteni, hogy a legtöbb esetben léteznek további anyagi szimmetriák bizonyos síkokra vonatkozóan. Így például monoklin anyagoknál (egy anyagi szimmetria síkkal rendelkeznek) 13 a független anyagállandók száma, $3 D$ ortotrop (vagy speciálisan ortotrop ) anyagoknál pedig 9 .

\subsection{Anyagállandók egy általánosan ortotrop rétegre}

Az említett $3 D$ ortotrop anyag esetében az anyagállandók mátrixa az alábbi szerkezetü:

$$
[\underline{\underline{D}}]=\left[\begin{array}{cccccc}
D_{11} & D_{12} & D_{13} & 0 & 0 & 0 \\
D_{21} & D_{22} & D_{23} & 0 & 0 & 0 \\
D_{31} & D_{32} & D_{33} & 0 & 0 & 0 \\
0 & 0 & 0 & D_{44} & 0 & 0 \\
0 & 0 & 0 & 0 & D_{55} & 0 \\
0 & 0 & 0 & 0 & 0 & D_{66}
\end{array}\right] .
$$

A gyakorlatban az anyagi viselkedést könnyen mérhető mérnöki anyagállandók formájában lehet egyszerüen megadni, ezért mi is ezt a megközelítést fogjuk preferálni a továbbiakban. Egy speciálisan ortotrop anyag esetén - felhasználva a 2. ábra jelöléseit - ezek az $E_{1}, E_{2}, E_{3}, G_{12}, G_{13}, G_{23}, v_{12}, v_{13}$ és $v_{23}$, ahol $E_{i}$ a rugalmassági modulusz, $G_{i j}$ a csúsztató rugalmassági modulusz és $v_{i j}$ a Poisson tényező $(i, j=1,2,3)$. Ezek ismeretében közvetlenül megadhatók a (10) mátrix elemei: 


$$
\begin{aligned}
& D_{11}=\frac{1}{E_{1}}, D_{12}=-\frac{v_{21}}{E_{2}}, D_{13}=-\frac{v_{31}}{E_{3}}, \\
& D_{21}=-\frac{v_{12}}{E_{1}}, D_{22}=\frac{1}{E_{2}}, D_{23}=-\frac{v_{32}}{E_{3}}, \\
& D_{31}=-\frac{v_{13}}{E_{1}}, D_{32}=-\frac{v_{23}}{E_{2}}, D_{33}=\frac{1}{E_{3}}, \\
& D_{44}=\frac{1}{G_{12}}, D_{55}=\frac{1}{G_{13}}, D_{66}=\frac{1}{G_{23}}
\end{aligned}
$$

Lineáris algebrából ismeretes, hogy egy szimmetrikus mátrix inverze is szimmetrikus, következőleg fennállnak az alábbi azonosságok:

$$
\frac{v_{21}}{E_{2}}=\frac{v_{12}}{E_{1}}, \frac{v_{31}}{E_{3}}=\frac{v_{13}}{E_{1}}, \frac{v_{23}}{E_{2}}=\frac{v_{32}}{E_{3}}
$$

A 2. ábrán $l=L$ a szálirány, $2=T$ a rá meröleges irány, valamint $X, Y$ jelölik a vonatkoztatási rendszer tengelyeit. Az általános szabály szerint [17] a $\theta$ szög pozitív, amennyiben az óramutató járásával ellentétesen forgatunk a referencia tengelyhez képest az anyagi irány megadásához.

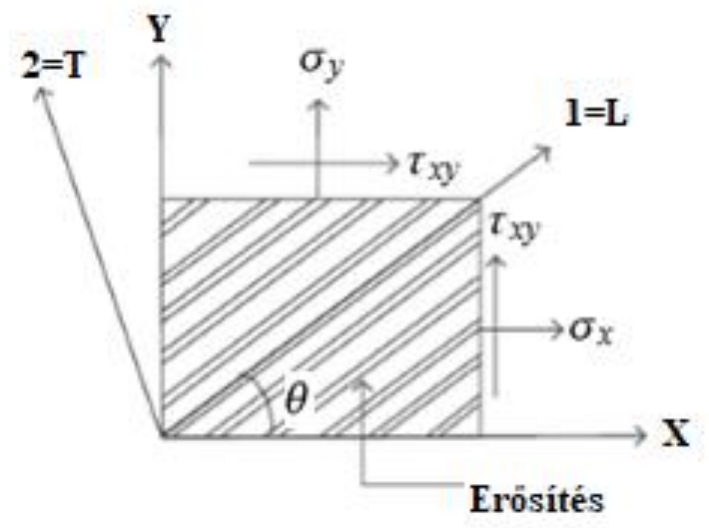

2. ábra. Ortotrop réteg szálirányának orientációja a referencia tengelyhez képest. [18]

\section{Numerikus modellezés}

A továbbiakban a kompozitok tömegcsökkentés formájában elérhető előnyét kívánjuk szemléletesen bizonyítani a „hagyományos” anyagokhoz képest. A vizsgálatok az Abaqus CAE 6.13 [19] szoftver segítségével lettek elvégezve.

A bizonyítás egy lemez végeselemes (VE) vizsgálatán keresztül kerül bemutatásra. A lemezt először egy „hagyományos” anyagnak tekinthető lineárisan rugalmas, izotróp, általános acélból modellezzük. A vizsgálat célja az elmozdulás-mező meghatározása, amit egy felületen megoszló külső terhelés (nyomás) és a test önsúlya idéz elö. Ezután egy ezzel megegyező felületü T300/5208 grafit/epoxy kompozitból készült egyrétegủ lemez vizsgálata kerül bemutatásra. 


\subsection{Az acéllemez vizsgálata}

Az acéllemez méretei 100/200/0,5 mm (szélesség/hosszúság/magasság), anyagi jellemzői a [20] forrásból származnak.

Az időben állandósult terhelés egy összesen $10 \mathrm{~N}$ eredő erőnek megfelelő konstans megoszló felületi nyomás $(0,0005 \mathrm{MPa})$ és a lemez önsúlya, ami $g=9,81 \mathrm{~m} / \mathrm{s}^{2}$ feltételezése mellett $0,004905 \mathrm{~N}$ (tehát a saját tömeg $0,078 \mathrm{~kg}$ ). A peremfeltételeket tekintve a lemez peremei nem tudnak elmozdulni, de az elfordulások megengedettek, tehát lényegében csuklókkal van körben megtámasztva. Az alkalmazott háló $5 \mathrm{~mm}$-es, rendezett négyzet formájú $S 4$ típusú (Standard/Linear/Shell) elemekből épül fel, mint azt a 3. ábra is mutatja.

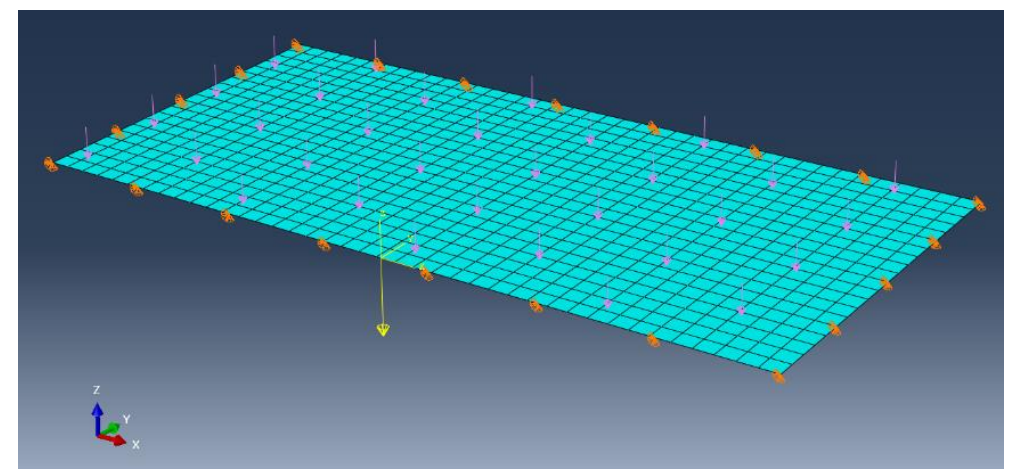

3. ábra. Az acéllemez VE modellje.

A szimuláció konvergáltnak tekinthető eredményeként a 4. ábra alapján látható, hogy a legnagyobb elmozdulás a lemez középső részén megy végbe (a megtámasztásoktól legtávolabb).

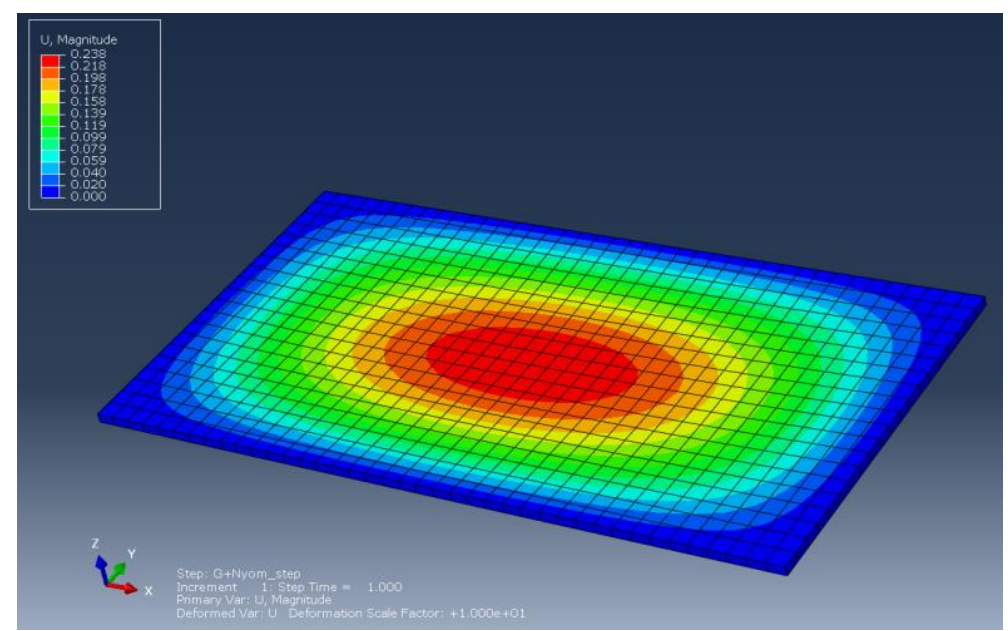

4. ábra. Az acéllemez elmozdulás-mezöje mm-ben megadva.

\subsection{A kompozit lemez analízise}

A következő lépés a kompozit lemez vizsgálata az Abaqus Composite Layup moduljának segítségével. A használt anyagmodell a [6] forrás alapján készült. Az egyes anyagjellemzők értékeit az 1. táblázat tartalmazza, ahol $\rho$ az átlagos sürüség. 
1. táblázat. A T300/5208 anyag anyagjellemzöi.

\begin{tabular}{|c|c|}
\hline Anyagjellemzö & Értéke \\
\hline$E_{1}$ & $132.4 \mathrm{GPa}$ \\
\hline$E_{2}=E_{3}$ & $10.76 \mathrm{GPa}$ \\
\hline$G_{12}=G_{13}$ & $5.65 \mathrm{GPa}$ \\
\hline$G_{23}$ & $3.38 \mathrm{GPa}$ \\
\hline$v_{12}=v_{13}$ & 0.24 \\
\hline$v_{23}$ & 0.49 \\
\hline$\rho$ & $1800 \mathrm{~kg} / \mathrm{m}^{3}$ \\
\hline
\end{tabular}

Kezdetben az acéllemez felületével, vastagságával, terhelésével, megfogásával és hálózásával is megegyező kompozit lemez lett szimulálva. A próbaszámításoknál az ideálisan összekapcsolt rétegek számának- és a bennük lévő szálak orientációjának szisztematikus változtatásával az alábbi következtetések vonhatók le:

- Azonos orientáció mellett nincs értelme rétegeket megkülönböztetni.

- A szálak minél inkább párhuzamosak az $Y$ tengellyel (ami a terhelés szempontjából a kitüntetett irány, de nem a terhelés iránya), annál merevebbé válik a kompozit lemez is.

- Az itt használt kompozit az acél vastagságában nem képes olyan merevséget nyújtani, mint az acél. Ennek magyarázata lehet, hogy a kompozit esetén a modulusz értékek általában nagyságrendekkel kisebbek, mint az acénál.

Ezen megfigyelések felhasználásával készült el a végleges modell, ami egyetlen réteget tartalmaz, melyben a szálak az Y tengellyel párhuzamosak. Ennek illusztrációját mutatja az 5. ábra. Mivel ezen cikk célja a legelőnyösebb eset megkeresése és részletesebb analízise volt. Más szálorientációk használata a feszültségek és deformációk szempontjából kedvezőtlenebb eredményre vezetne, így ezekkel bővebben nem foglalkoztunk.

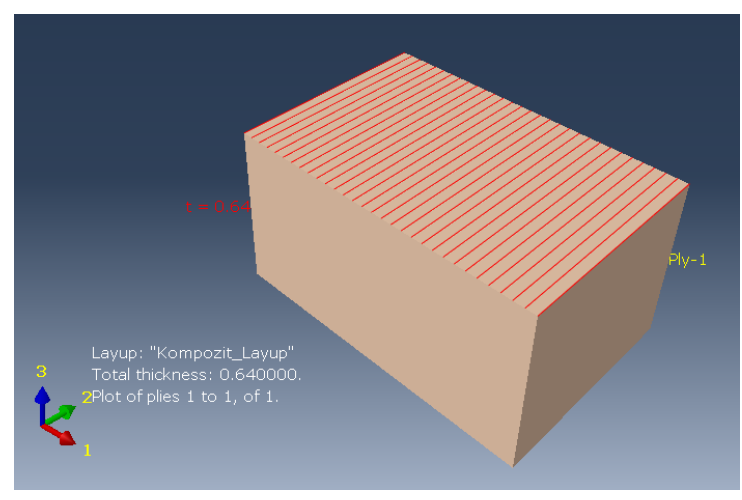

5. ábra. A végleges szálirány modellje.

Ahhoz, hogy a kellő geometriai merevség előálljon, a kompozit lemezt meg kell vastagítani 0,64 mm-re. Ez 28\%-os térfogat növekedést eredményez, ugyanakkor a kisebb sürüség okán így is jóval kisebb tömegü a kompozit lemez az acélnál $(0,023 \mathrm{~kg}$, szemben az acél $0,078 \mathrm{~kg}$-os tömegével). A 6 . ábrán látható a kompozit lemez elmozdulás-mezője, mely a csúcsérték tekintetében lényegében megegyezik az acéléval, ugyanakkor látható, hogy az eloszlása más, nagyobb terület szenvedi el a maximálishoz közeli alakváltozást, mint az acél esetén. 


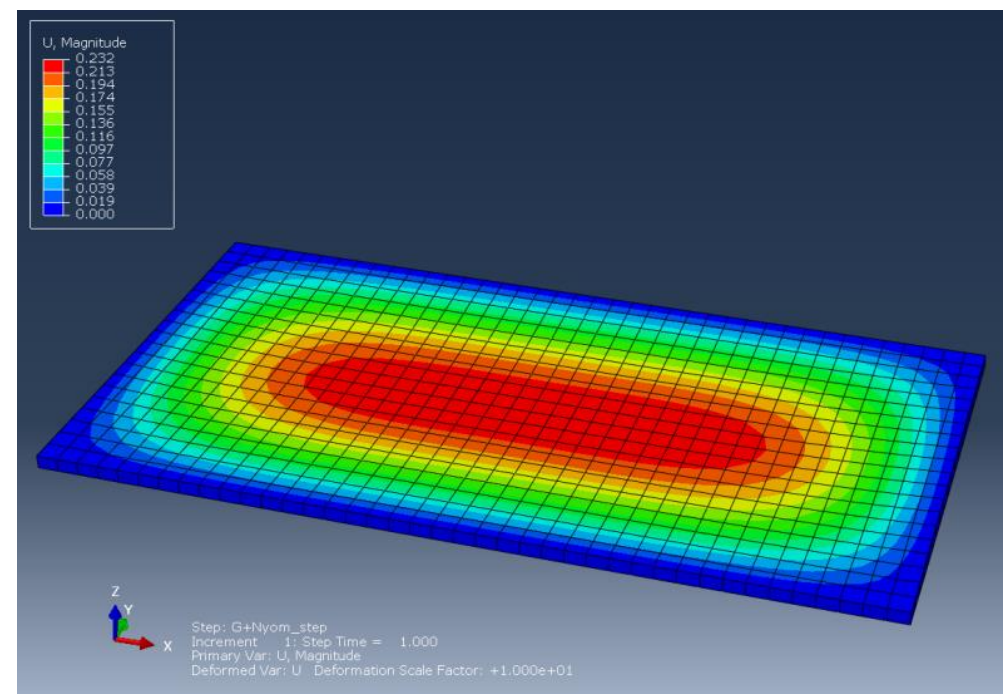

6. ábra. A kompozit lemez elmozdulás-mezöje mm-ben megadva.

\subsection{Az eredmények összehasonlítása}

Az elmozdulás-mezők eloszlásának jellegbeli különbsége további vizsgálatra ad okot. A 7. ábrán és 8 . ábrán láthatók a két lemez feszültség-mezői, melyeken megfigyelhetők a nagyság- és eloszlásbeli különbségek is.

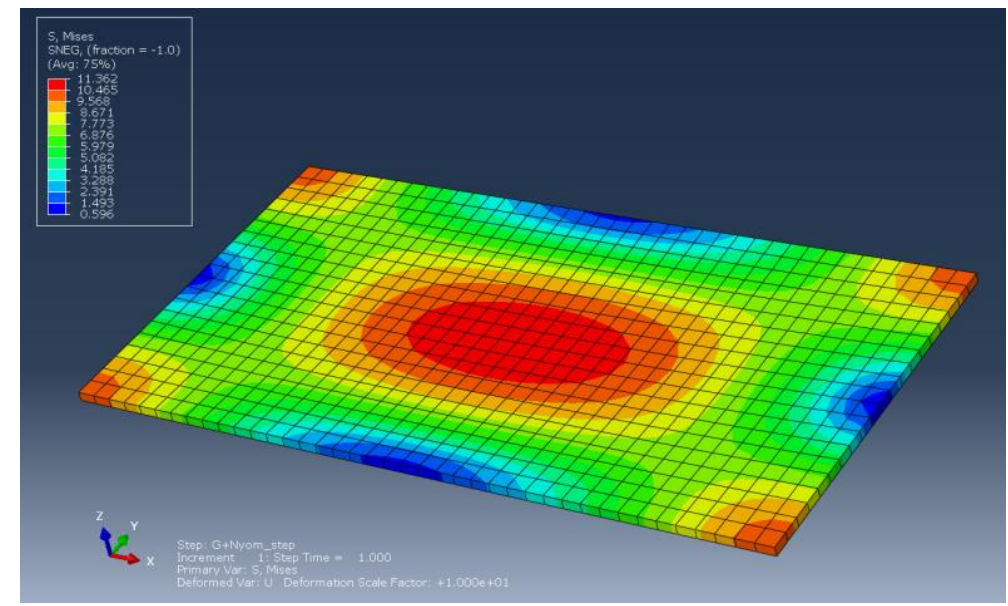

7. ábra. Az acéllemez feszültség-mezője MPa-ban megadva. 


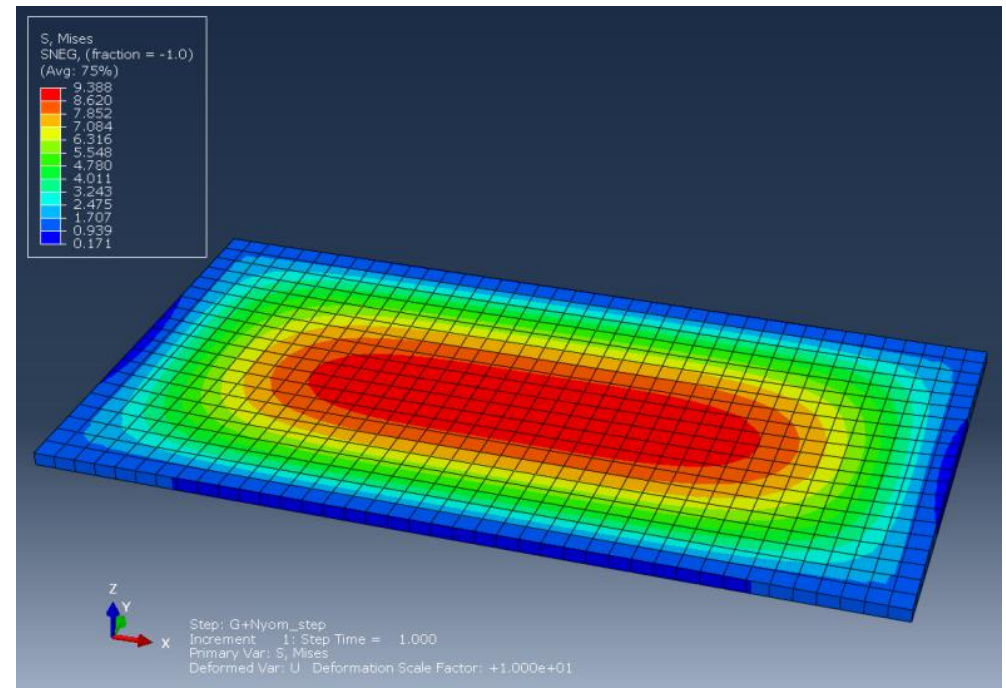

8. ábra. A kompozit lemez feszültség-mezöje MPa-ban megadva.

A fenti ábrákból jól látszik, hogy a kompozit lemez esetén a terhelés kedvezőbben, vagyis nagyobb területen, egyenletesebben oszlik el, és a maximális feszültség értéke is mintegy $2 \mathrm{MPa}-\mathrm{lal}(17,5 \%-\mathrm{kal})$ kisebb, mint a fémlemez esetén. A 9. ábra megmutatja a két lemez normális irányú elmozdulását a távolság függvényében. Az $X$ koordinátát a lemez szélétől indulva a szimmetriatengely mentén mértük. Az elmozdulások elöjele itt negatív, mivel a $Z$ tengely irányításával ellentétesen következnek be.

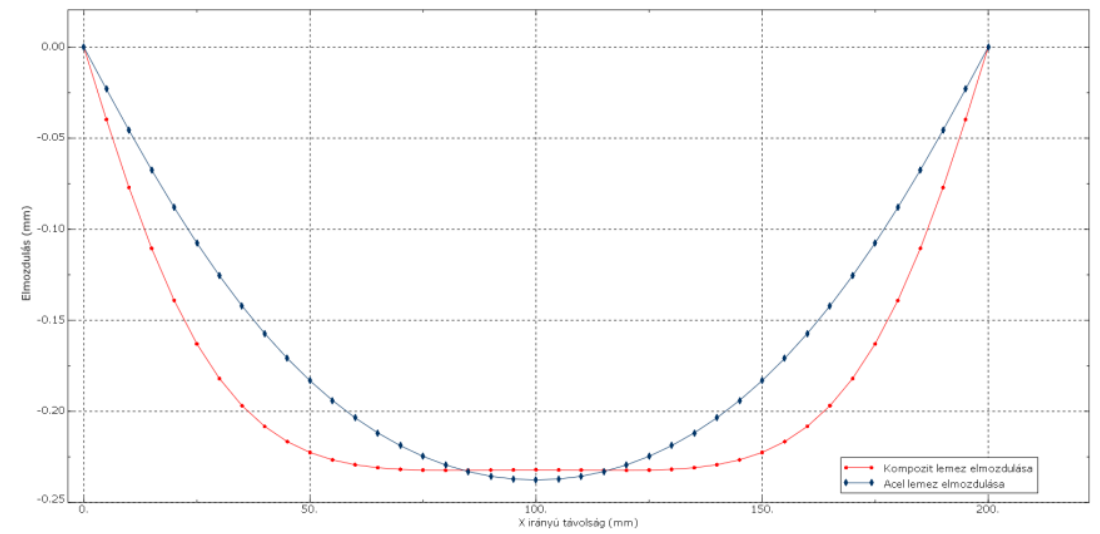

9. ábra. Lemezek normális irányú elmozdulásának összehasonlítása az X szimmetriatengely mentén.

\section{4. Összefoglalás}

Az előzőekben ismertettük a kompozitok általános jellemzőit, és anyagi viselkedését. Ezt követően egy egyszerü példában bemutatásra kerültek előnyeik a „hagyományos” anyagokkal szemben. A számpéldában az első lemez egy általános acél tulajdonságaival rendelkezik, ez a referencia, míg a második lemez grafit/epoxy kompozitként volt definiálva. A síklemezeket az önsúlyuk és egy felületi nyomás terhelte. Az eredményekből látható, hogy a kompozitok használata alapanyagként jelentősen egyenletesebbé tette a testben kialakuló elmozdulás és feszültség-mezők eloszlását, mindeközben 70\%os tömegcsökkentést is eredményezett. Azonban ez a kísérlet is egyszerüsített, eltekintettünk számos 
tényezőtől, mint például a szál és mátrix térfogatarányának hatásától, vagy az üregek jelenlététől az anyagban. Célszerü lehet többrétegü, különböző irányú szálakból álló modelleket is tesztelni, akár a rétegek közti kapcsolat nem ideálisnak vételével, beleértve a köztük lévő ragasztóanyag modellezését is.

\section{Irodalom}

[1] Görbe, Á.: Polimerek anyagszerkezettana és technológiája, Előadásvázlat, Budapesti Müszaki és Gazdaságtudományi Egyetem, 2018.

[2] Hargitai, H.: Polimer kompozitok alapanyagai, tulajdonságai, kompozitmechanikai alapok, Előadásvázlat, Széchenyi István Egyetem, 2011.

[3] Kollár, L. P., Springer, G. S.: Mechanics of Composite Structures, Cambridge University Press, 2003. https://doi.org/10.1017/CBO9780511547140

[4] Majeed, M. A.: Deformations of in-plane loaded unsymmetrically laminated composite plates, $\mathrm{PhD}$ dissertation, Faculty of the Virginia Polytechnic, Institute and State University, 2005. https://doi.org/10.2514/6.2005-2099

[5] Akavci, S. S., Yerli, H. R., Dogan, A.: The first order shear deformation theory for symmetrically laminated composite plates on elastic foundation, Arabian Journal for Science \& Engineering, Vol. 32. Issue 2B, 2007. https://doi.org/10.1515/SECM.2006.13.2.79

[6] Mahmud, J., Hussain, A. K., Rahimi, N., Rahim, M. A.: Failure analysis of composite laminate based on experiment-simulation integration, Current Research in Malaysia, Vol. 2. No. 2. pp.722, 2013.

[7] Kam, T. Y., Sher, H. F., Chao, T. N., Chang, R. R.: Predictions of deflection and first-ply failure load of thin laminated composite plates via the finite element approach, International Journal of Solids and Structures, Vol. 33. No.3. pp.375-398, 1996. https://doi.org/10.1016/0020-7683(95)00042-9

[8] Bojtár, G.: Textil kompozitok anyagtulajdonságainak numerikus modellezése, Szent István Egyetem, Gödöllö, 2019.

[9] Tóth, T. B.: Ortotrop rétegelt kompozit lemez lengéstani analizise, Budapesti Müszaki és Gazdaságtudományi Egyetem, 2015.

[10] Kovács, Gy.: Ortotrop rétegelt kompozit lemez lengéstani analízise, Miskolci Egyetem, 2004.

[11] Ramu, I., Mohanty, S. C.: Modal Analysis of Functionally Graded Material Plates Using Finite Element Method, Procedia Materials Science, Vol. 6. pp.460-467, 2014. https://doi.org/10.1155/2014/247932

[12] Filippi, M., Carrera, E., Zenkour, A. M.: Static analyses of FGM beams by various theories and finite elements, Composites Part B: Engineering, Vol. 72. pp.1-9., 2015. https://doi.org/10.1016/j.compositesb.2014.12.004

[13] Gönczi, D.: Thermoelastic analysis of thick-walled functionally graded spherical pressure vessels with temperature-dependent material properties, Journal of Computational and Applied Mechanics, Vol. 12. No. 2. pp.109-125, 2017. https://doi.org/10.32973/jcam.2017.008

[14] Kiss, L. P.: Nonlinear stability analysis of FGM shallow arches under an arbitrary concentrated radial force, International Journal of Mechanics and Materials in Design, Vol. 16. pp.91-108., 2020. https://doi.org/10.1007/s10999-019-09460-2

[15] Gönczi, D.: Analysis of rotating functionally graded disks with arbitrary material properties, Acta Technica Corviniensis - Bulletin of Engineering, Vol. 4. pp.1-6, 2018. 
[16] Ecsedi, I., Gönczi, D.: Thermoelastic stresses in nonhomogeneous prismatic bars, Annals of Faculty of Engineering Hunedoara - International Journal of Engineering, Vol. 13. No. 2. pp.4952, 2015.

[17] Iyengar, N. G. R.: Composite Materials and Structural Analysis, MV Learning, 2016.

[18] Heiza, Kh. M., Meleka, N. N., Elwkad, N. Y.: Behavior and analysis of self-consolidated reinforced concrete deep beams strenghtened in shear, International Scholarly Research Network, Vol. 2012. Article ID 202171, pp.14., 2012. https://doi.org/10.5402/2012/202171

[19] Abaqus Standard User's Manual Version 6.13, 2017.

[20] http://www.matweb.com/search/datasheet.aspx?bassnum=MS0001 [Letöltés dátuma: 2020.03.29.] 